\title{
Migration, Youth, and Land in West Africa: Making the Connections Work for Inclusive Development
}

\author{
Mayke Kaag ${ }^{1}(0)$, Gerard Baltissen ${ }^{2}$, Griet Steel ${ }^{3}$ and Anouk Lodder ${ }^{4, *}$ \\ 1 African Studies Centre Leiden, Leiden University, 2300 RB Leiden, The Netherlands; kaag@ascleiden.nl \\ 2 Royal Tropical Institute, 1092AD Amsterdam, The Netherlands; g.baltissen@kit.nl \\ 3 Department of Human Geography \& Planning, Utrecht University, 3584 CB Utrecht, The Netherlands; \\ g.steel@uu.nl \\ 4 VNG International, 2500GK The Hague, The Netherlands \\ * Correspondence: anouk.lodder@vng.nl
}

Received: 22 February 2019; Accepted: 4 April 2019; Published: 8 April 2019

check for updates

\begin{abstract}
This paper presents the results of a short-term research project conducted in 2017/2018 on the various ways in which migration and land dynamics in West Africa are intertwined. Contrary to much conventional (policy) thinking in the European Union (EU) today, our point of departure is not that migration is the problem to be solved - nor that (access to) land is the straightforward means to discouraging migration. Drawing on local case studies in four West African countries, this research aims to shed light on the various relationships between migration and land, and to analyze to what extent they may contribute to or obstruct (local) inclusive and sustainable development in Mali, Senegal, Burkina Faso, and Benin. In doing so, we aim to offer food for thought concerning possible ways for making the connection between migration and land more fruitful and productive for as many people as possible, especially in relation to the opportunities and constraints facing different categories of West African youth.
\end{abstract}

Keywords: migration; land governance; youth; West Africa

\section{Introduction}

Over the past few years, discussions on migration in Europe have become ever more alarmist, narrowly focusing on how to stop African migration towards the European Union. Especially in the heated media debates on boat refugees, the discussion basically focuses on the so-called massive exodus from Africa to Europe. There is little concern for gaining perspective, for instance, by paying attention to the (rather mundane and reasonable) reasons why people are migrating - or recognizing that $50 \%$ of international migration is happening between African countries [1]. West Africa sees seven times more migration movements within the region than to European countries [2]. The category of people on the move is diverse, including refugees fleeing war and disaster, skilled and unskilled labor migrants, students, traders, and pastoralists [3-6].

In view of the fact that about half of sub-Saharan Africa's population is under 25 years of age, it may not come as a surprise that a substantial number of international migrants are young people. Many youth in West Africa consider migration as a promising way to improve their lives [7-9]. Many factors influence (young) people's decisions to move, from economic fluctuations and instability, and high unemployment and underemployment rates (particularly among the youth) to the search for higher education, land scarcity, and climate change [5,6]. Improved transportation, the spread of mass media, and advances in communication technologies and remittance mechanisms promise easier travel while enabling migrants to retain strong economic, social, and political ties with 'home' [10]. This makes transcontinental migration to Europe - but also increasingly to Asia and the Americas-a real or 
imagined possibility for a number of West African youth. Their families may pool resources to make this happen, as decisions to migrate are often not an individual but a family affair, the family hoping to get a return from their investment [11].

Migration patterns cannot be understood without considering the geography of land investments. The lack of land and appropriate inheritance systems have made many young people migrate to pursue livelihoods elsewhere, both in and outside of agriculture. At the same time, migrants are often the main investors in their home countries. They send huge amounts of remittances back home to invest in land and real estate, be it in cities or in rural areas [12-15]. The economic value of this type of investment and its meaning in terms of productivity have been widely discussed, but less attention has been paid to how it influences processes of socio-economic inclusion and exclusion (see also [11]). It is clear that land investments may create new opportunities for some, while causing displacement, forced evictions, and marginalization for others. This raises the question as to how various categories of West African youth may navigate these processes, including what the impacts on them, their families, and wider society might be.

These observations show that the main assumptions underlying current (policy) debates on West African migration are too simplistic and straightforward. Worse still, they hinder exploring possible avenues or barriers to inclusive development that may be hidden in the land-migration nexus. Therefore, we argue that a more nuanced and multifaceted understanding of the relationship(s) between land and migration in the region is needed. In this paper, we particularly aim to shed light on the various relationships between migration, youth, and land, and to analyze how far they may contribute to or obstruct (local) inclusive and sustainable development in Mali, Senegal, Burkina Faso, and Benin. Drawing on local case studies in these four West African countries, we analyze how land investments and migration trajectories of West African youth and their families are interrelated. By exploring this general research question, we offer food for thought on how to make the connection between migration and land more fruitful and productive for as many people as possible, especially in relation to the opportunities and constraints facing different categories of West African youth. Before outlining the research approach and methodology used and delving into the results, we start by taking a closer look at the links between youth migration, land, and inclusive development.

\section{Migration, Land, and Youth: Making the Connections Work for Inclusive Development}

Inclusive development can be defined as 'development that includes marginalized people, sectors, and countries in social, political and economic processes for increased human wellbeing, social and environmental sustainability, and empowerment' [16]. For a long time, development was mainly considered a question of economic growth. However more recently, the relational aspect - including questions of power and inclusion and exclusion - is increasingly receiving attention. This perspective implies that development is concerned with both an improvement in income and wellbeing, as well as the distribution of outcomes across the population. In this respect, the 2018 Africa Development Dynamics report [17] states that despite sustained growth, Africa shows only limited progress in achieving the Sustainable Development Goals. While Africa's economy grew by $4.7 \%$ per year between 2000 and 2017 (making it the world's second fastest-growing region), this has not translated into improved overall wellbeing. The report therefore recommends addressing poverty by focusing on reducing inequality. It also states that for this to happen, improving the availability of quality jobs is key - especially as, if current trends continue, the share of vulnerable employment in Africa will remain at $66 \%$ until 2022, with an estimated 282 million workers now being in vulnerable employment [17].

It is clear that the discussion on land, (youth) migration, and opportunities for inclusive development in West Africa needs to be seen against this background of the lack of opportunities for earning a decent livelihood locally. Ironically, in the current neo-liberal era, the effects of structural adjustment programs and decentralization have had a profound impact on African economies and political regimes and have undermined the central role of the state, thus affecting the latter's capacity to foster national and local development [18]. At the same time, intensified globalization has 
both facilitated global public and private investment flows towards Africa [19], with promises of economic growth, and population movements in and from Africa, including opportunities for building livelihoods transnationally [20-25].

Central and local governments in West Africa have a stake in both transnational migration and land dynamics in their country. In the field of migration, they are, on the one hand, worried about the loss of human capital, but on the other, in favor of (youth) migration, as remittances might contribute to local and national economic development and offer new opportunities for unemployed youth who are considered a potentially destabilizing factor in society $[26,27]$.

At the same time, land has progressively become an asset, particularly in peri-urban areas - and it can bring great gains. Increasingly, private investors, civil servants, and the state have become engaged in land markets and land speculation [28]. In rural areas, in the context of land degradation and fragmentation, there is an increasing conversion of traditional or communal land rights to private tenure, leading to the enclosure of traditional grazing areas, deforestation, and the facilitation of agricultural land grabs by outside commercial interests [29]. Traditional, customary, and small-scale users may subsequently be pushed off the land altogether. They may respond by rising stocking rates and/or intensifying farming activities on lands they can still access, change their livelihood activities, and/or may increasingly engage in labor migration to offset lost income.

The high migration rates do not automatically mean that West African youth are no longer interested in agriculture. They may see no future in 'traditional' family-based subsistence agriculture, which is considered hard work for low yields and barely enough to feed their families. However, they are interested in family farms producing high-value crops, in agricultural diversification, and in well-developed value chains offering job opportunities in marketing and processing (see, for instance, [30]). But young people also need the appropriate skills - which they cannot always acquire easily. Without knowing the right people, being from the right community, or having the money to buy their way into a job, they have difficulties in getting ahead in societies where careers are generally built on social relationships rather than on individual merit. More generally, young people are often particularly penalized by precarious access to land and land-holding fragmentation, the lack of targeted and accessible rural financial products and services, and conflict and post-conflict transition processes. Young women are often at the greatest disadvantage in all of these areas [31].

The foregoing indicates that land and migration are important variables in both processes of exclusion and inclusion in West-Africa, and that youth are important actors in, as well as strongly affected by, these processes. An increased understanding of how this works in practice will thus contribute to our knowledge on (possible) pathways to inclusive development. In the empirical remainder of this paper, we will therefore scrutinize the land-migration nexus in the various case study locations from the perspective of inclusive development, with a special focus on West African youth. We will consider, on the one hand, how categories of West African youth are positioned in processes of marginalization related to land and migration, and, on the other hand, how they (may) contribute to, and profit from, processes of social inclusion and redistribution.

\section{Research and Methodology}

To gain a better understanding of the various connections between migration and land dynamics, exploratory qualitative field research was conducted in selected sites in Benin, Burkina Faso, Mali, and Senegal (see Figure 1). It covered rural, urban, and peri-urban areas, with a particular focus on various categories of West African youth. The four countries have their history of French colonization in common, which is (among other things) still apparent in legislation, currency, and political and economic ties. In addition, all four countries have a high population growth and an extremely youthful population: in each, more than $60 \%$ of the population is under the age of 25 . In recent years, the case-study countries have experienced relatively strong GDP growth, at around 6\%, with Senegal (7.2\% in 2017) doing slightly better than the others. However, all four countries have little growth in the productive sectors. In addition, there is still widespread poverty and vulnerability to climate 
variability is high. Mali in particular has experienced political turmoil and military violence in the last few years [32].

In Benin, research was conducted in the rural communities of Dogbo and Klouékanmè (Kouffo Department) in the rather densely populated southwest of the country. Data were obtained through a literature review; observations; and 32 semi-structured interviews with male and female migrants and their families, representatives of youth associations, members of the rural council, and municipality and project officers.

Research in Burkina Faso covered three sites: the rural municipality of Béguédo, the urban municipality of Sapouy, and the rural municipality of Bama in the peri-urban area of Bobo-Dioulasso. In total, 13 semi-structured interviews and eight focus group discussions were held, with diverse categories of local stakeholders (youth, local authorities, migrants, and other family representatives).

In Mali, research was conducted in the municipality of Duguwolowula, an agro-pastoral zone located in the Koulikoro Region northeast of Bamako. Here, the data were obtained through a literature review, observations, life stories, and eight semi-structured interviews with diverse categories of local stakeholders.

Finally, research in Senegal focused on Keur Massar, a peri-urban center of growth and an investment hub in the northeast of the capital Dakar. Research included a literature review, observations, informal conversations, one focus group discussion with local youth, and 12 semi-structured interviews with representatives of diverse categories of stakeholders (local youth, male and female representatives of local families, local authorities, and officials at the major's office of Keur Massar).

Starting from the question about how land investments and migration trajectories of West African youth and their families are interrelated, each case study has explored the influence of remittances, return migration, and character of the diaspora (old, new, males, families) on land investments. They have also examined the influence of land degradation, land speculation, land ownership, and land investment on migration. However, rather than prescribing a strict format, the researchers for each of the four case studies were relatively free to choose their particular focus, depending on the characteristics of their respective settings. Research was conducted by teams of local researchers (except for the Senegal case study, which was done by Kaag). Field reports were then produced [33-35] (see also [36]). The combined research results are presented in the following section.

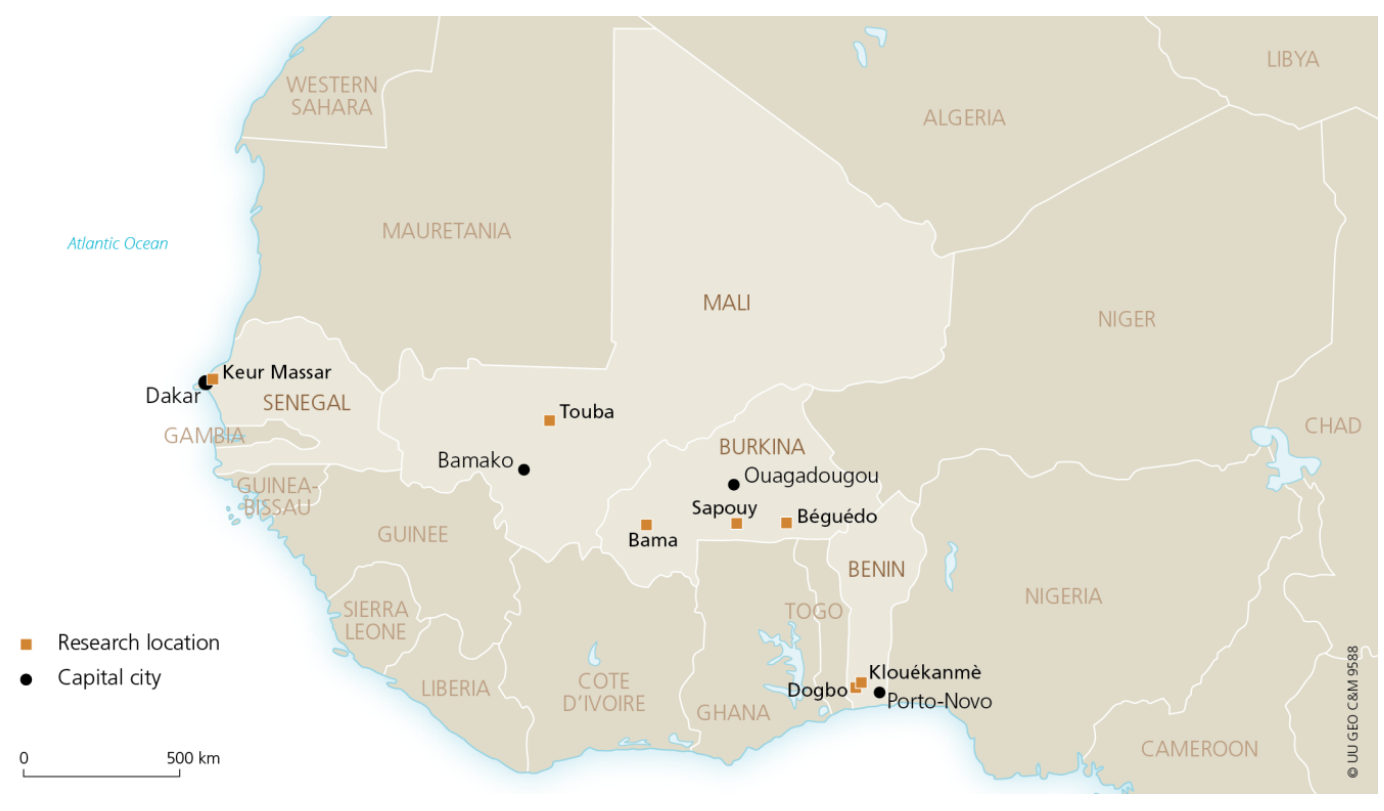

Figure 1. Overview of research locations. 


\section{Research Results}

\subsection{Mobility Patterns}

The studies confirm the observation in the literature that mobility has a long tradition in West-Africa. Current mobility should be seen as building on, and an extension of, older patterns of migration, including the rural exodus that started in the 1970s and 1980s, partly as a consequence of the severe droughts that hit the region hard. Destinations and trajectories have changed over time, but most migration is still within the sub-region, with Côte d'Ivoire, Ghana, Gabon, and Nigeria as important destinations (see also [1,4]). Thus, in Benin, people used to leave their home villages to do seasonal work on the coffee or cacao plantations in Ghana and Côte d'Ivoire. Nowadays, Nigeria is becoming a more and more popular destination for migration, partly related to the rise of new working opportunities in its rapidly expanding cities. It was reported that many young Beninese men work in the construction sector (such as bricklaying, tiling, carpeting, and decorating) in Nigerian cities, while young women are employed as domestic workers.

The crisis in the Côte d'Ivoire in the early 2000s, inter alia, has also made more migrants from the case-study countries undertake the longer journey towards Europe and the United States. In Europe, Italy became an important destination when, at the end of the 1980s, France and Germany installed visa requirements (see also [37]), and is still important now. In Béguédo in Burkina Faso, for instance, according to its mayor, more than 3000 citizens of the municipality now live in Italy. This represents almost $15 \%$ of the current population of the municipality. It also illustrates the importance of chain migration: young people following in the footsteps of migrants in their family and/or community who left earlier. The research in Senegal showed that older patterns of emigration to France and Italy have recently shifted to destinations beyond 'Fortress Europe' [38] (with the latter's extension into Northern Africa also hindering circulation in the larger sub-region). In contrast, older resident men spoke about their years in Italy, and how the sons who have left over the last few years have increasingly taken Latin America as a destination (see also [39]).

Young people may move for a number of reasons. They may move in their endeavor to become economically independent, for example, to acquire their own house, land, or other assets. However, as also discussed elsewhere in the literature, for young West Africans, migration may also constitute a rite of passage in the process of socially becoming an adult [40]. In Béguédo in Boulgou Province in Burkina Faso, interviewees noted the importance of the practice of migration as a sociocultural fact. According to an agricultural officer, at least $75 \%$ of young people between the ages of 20 and 35 have one experience of migration and $90 \%$ of families have at least one migrant son.

Migration to other regions in the same country, such as to the mining sites in Burkina Faso, is mostly circular in the short term, with people visiting their home community regularly. Often, this migration is linked to the search for labor opportunities in the dry season, with people returning to their fields when the rainy season starts. On the other hand, migrants may also be attracted by agricultural labor opportunities, for instance, during harvesting time. Emigration, in contrast, particularly outside of the West African region, often involves migration trajectories of many years. For instance, for the research site in Mali, it was reported that a considerable proportion of migrants (at least $25 \%$ ) returns after more than 20 years of absence. Most migrants, however, keep in touch with the local community by sending remittances to family and for community projects. Associations play an important role in social organization and the transfer of funds from remittances [41]. In Touba in Mali, for instance, the local association is composed of resident members, nationals living elsewhere in Mali, and migrants living abroad. Some youth remain in the municipality for the implementation and monitoring of investments of the association. Often, investments are not made primarily in agricultural land, but in consumption (such as food, health, education), family assets (such as housing, infrastructure), or trades and services. 


\section{2. (Opportunities for Having) Access to Land}

In most research sites, customary land governance is still prominent. In the research area in Mali, for instance, the municipal council has little involvement in land acquisitions or investments, although it is officially required that it approves any land registrations up to 2 hectares. In practice, decisions on land transactions continue to be made by customary chiefs, including village chiefs, land chiefs, and lineage heads, who remain at the heart of land management and community investments. Women and transhumant pastoralists have access to land resources. For instance, women's groups may ask for plots for collective gardening and women may get a plot from their husband on a yearly basis. Customary arrangements thus assure security of access and use, but prevent women from actual land acquisition. In addition, customary rules hinder their full participation in socio-political spaces and decision-making processes in rural areas. These often remain monopolized by male traditional leaders and local elites (see also [42]). It is sometimes expected that returning migrants may act as advocates of 'modernization' by promoting modern land administration and land titling. In the research area in Mali, however, return migrants' compliance with the customary system of land governance, in the sense that they accept the land offered to them by the village leaders, seems to reinforce the primacy of customary chiefs.

In the rural research sites in Burkina Faso and Benin, land has become scarcer. Among other things, this is because of the interest of elites from outside the community in investing in and acquiring land. As was observed in Sapouy in Burkina Faso, land acquisitions by these 'new' actors contradict previous 'traditional' land agreements, and have caused some resident families to migrate further south. This suggests that in these areas, a more strained relationship is developing between the local customary system and state law, leading to a more hybrid form of land governance. In the Béguédo municipality in Burkina Faso, land availability is insufficient, making it virtually impossible (especially for youth) to acquire land. Many land conflicts are due to double allocations (multiple owners) and land sales that do not comply with regulatory procedures, be they customary or belonging to the state domain, while a cadastral plan is absent. The (re)claiming of land by traditional landowners led to a bloody land conflict in 1982. It needed the army's intervention to end this land dispute - which left a deep dissension between the two neighboring communities.

In the peri-urban areas, the overlapping of customary land rights and modern forms of individual property rights is still more advanced. In Keur Massar in Senegal, for instance, a transformation is taking place in which customary land rights are being progressively commercialized. In addition, prices for plots have risen strongly over the last 10 years, going up to FCFA 5 million for an allotted plot and up to FCFA 9-10 million for an un-allotted plot, due to the strong interest by (foreign) investors and rural estate developers, elites from the Dakar region, and transnational migrants [36]. However, instead of formal law offering legal clarity and tenure security, as is often claimed by advocates of modern land titling, the current system is rather hybrid and fluid, while illegal, double, and unregistered sales are creating confusion.

Many transnational migrants who want to invest in Keur Massar do not originate from the area, but come from other parts of Senegal. This means that they need a local broker to find out information about plots for sale, current prices, and local owners and their form of ownership, for negotiating a good deal. While there are online offers of plots of land, it is commonly assumed that local personal contacts are needed to facilitate and accompany the process of land acquisition. Knowing someone personally-particularly when the connection has come about by mutual acquaintances, kinship, or ethnic bonds-creates trust. This is needed because land market and land rights are opaque and also because state housing agencies work through personal networks rather than through objective and written rules. An older informant narrated how staff of state agencies responsible for land registration may also profit from the brokerage system: 'There are for instance brokers who are able to sell a plot for 10 million, while this plot's official value is only 5 million FCFA. The state office then makes a contract for the official amount, and the 5 million is then distributed between the broker and the person(s) of the state office involved'. 
In the urban areas, young people are finding it increasingly difficult to access affordable land because of soaring prices. Local young men cannot afford these prices and are pushed to more marginal neighborhoods further afield. In the rural research sites, it was reported more generally that the lack of access to land was a reason for young men to migrate. The reasons for this include population growth, environmental degradation, and fragmentation of family land through inheritance. It should be noted, however, that youth also indicated that they were less interested in traditional subsistence agriculture. Instead, they would prefer to apply modern farming technologies and integrate into new value chains. However, they lack the financial means for initial investments, hence their quest to look elsewhere to earn money.

How women's access to land is related to migration is even more difficult and complicated to analyze. When men migrate, women may become de facto household heads. Their room to maneuver in terms of actual decision-making power on land use and on the use of remittances could not be established in the current short-term research. However, other studies have suggested that their actual empowerment is rather limited, as women tend to remain under the custody of the extended family [43] (see also [44]).

\subsection{The Migration-Land Nexus: Rural Versus Urban Dynamics}

As has become clear, there are large differences between rural communities where the pressure on land is (still) low and rural areas where land pressures are increasing, on the one hand, and (peri-)urban centers, particularly peri-urban areas around big cities, on the other hand. The case studies have particularly underlined that in the rural areas, increasing land pressures, but also examples of successful migration, stimulate emigration, and that requests for land by (returning) migrants can still be accommodated, in part because their remittances to the community are highly appreciated. In Touba in Mali, for instance, we saw that return migrants were able to access family land. They can also easily acquire land if it does not exceed 2 hectares. There is little opposition to giving land to returning migrants, especially if they have sent money to the family or the community over many years. In general, land and migration are still very much organized in the community and by customary arrangements.

In urban areas, transnational migrants have become a category of investors in urban space, mainly in property, in a situation of high competition (among others, by public and private companies, development projects, and political elites), and act in a more fluid setting of overlapping customary and commercialized rights. In the process, peri-urban agricultural land is increasingly being transformed into plots for real estate. Thus, throughout Keur Massar, one finds improved and new buildings at different stages of completion, like in other parts of Dakar [14,15] and elsewhere in urban West Africa.

Houses built through diaspora investments are often long-term projects of incremental building (see also [45]). These depend on how well the migrant fares abroad and how much he is able to save and send home. We spoke to a mason working on the third storey of a house in Keur Massar owned by a Senegalese migrant working in France. He told us that the construction of the house had started in 2003 and that the second storey had been added in 2005. Since then, the ground floor had been occupied by tenants and the second storey by the migrant's family. It was only in 2018 that the third storey could be finalized. One of the migrant's younger brothers was overseeing the work.

Another young local entrepreneur told us that he specialized in fancy lowered ceilings with integrated lights. His clients are mainly modou-modou (a term commonly used in Senegal to refer to Senegalese international migrants, meaning someone who works hard under difficult circumstances) as local people cannot afford the price. He makes a good living out of it, but also said that his younger brother, despite being in the same lucrative business, had decided to try to migrate to Europe and was in Morocco waiting for a chance to cross the Mediterranean. This illustrates that opportunities in the urban economy which are partly fueled by migrant investment may also stimulate new migration. 


\section{Discussion: The Land Migration Nexus and Dynamics of Inclusion and Exclusion}

The case studies underscore that in West-Africa, migration should be treated as a given and is an indispensable element in many local livelihoods in the region. In addition, the case studies show that migration and land dynamics are interwoven in many different ways, among other things, depending on the local context, personal preferences and strategies, and the shape of transnational connections.

Young people, mainly men, migrate because 'young people have always done that' - it may even be considered as an important rite of passage- and because they want to earn money for their families and community. The latter is particularly important in areas where there are solid feelings of attachment and belonging to a specific locality, such as in the rural areas in our case studies. In urban areas, migrants tend to think more in terms of supporting their families. Families and communities, in their turn, invest in migrants and benefit from the returns from migration.

Both rural and urban areas are targeted by migrant investments in land and infrastructure. Where land pressures are already high, such as in peri-urban areas, these contribute to the present 'land rush' and to soaring land prices, which means that local youth can no longer afford to buy land and are pushed to more marginal areas. On the other hand, migrant investments in housing and the like also create opportunities for local youth, such as brokerage and employment in construction. In low-pressure contexts in rural areas, migrant remittances often support families, but the case studies suggest that in many instances, they do not significantly propel economic productivity - which can be partly related to a lack of opportunities for creating added value in the agricultural sector.

Whereas in rural areas, transnational migrants often stand out for making an important contribution to local livelihoods and as such are considered to be part of the local elite, in urban contexts, migrants seem to be one actor among many in a complex, dynamic, and fluid land market. They are powerful because of their economic clout (be it that their income is often insecure, hence the practice of incremental building), but less so from the perspective of local politics, as they often come from other localities. Local brokers are thus important.

More generally, we can conclude that for migrants seeking opportunities to gain access to land, their connections to the local community are key (see also [11]), be it by proving their loyalty to their home community while away by sending remittances, or-if they aim to invest in a different location to where they originally come from-by relying on local brokers who can make that connection.

The case studies have shown that in rural areas in particular, traditional hierarchies are still prominent. Authorities such as village elders and male family heads still dominate decision-making in community and family matters, including access to land. However, migration does seem to offer openings to others, for instance, where women may become de facto family heads; and when young people are gaining respect and economic weight through migration.

How can we make the migration-land nexus more profitable and productive for as many people as possible? The dynamics elaborated here offer food for thought on both the bottlenecks and possible ways forward. Opportunities for circular migration, but also opportunities for investing in productive and sustainable land use, would be important pillars in such thinking.

In our view, the case studies have also indicated important and promising directions for further research. These include research on:

- Longer-term processes of inclusion and exclusion in various contexts, specifically concerning access to land and migration networks (see also [11]);

- The effects of mounting land pressure and urbanization on the nature of land conflicts, land tenure arrangements, and tenure security - and the role of migrants in these processes. The case studies seem to indicate a rural-urban continuum (see also [46]) in which customary arrangements offer security, but also a less flexible power framework (gerontocracy). Meanwhile, urbanization contributes to more opportunities for new economic elites, including migrants, but also to increasing inequality between old and new elites and poorer segments of the population; 
- Intrahousehold dynamics; in particular, how the specifics of the migration-land nexus over time shape opportunities for women in various settings;

- Local and translocal/transnational livelihood strategies and the role of land in these. For instance, is land currently a productive asset in translocal/transnational livelihood strategies?

The answers to these questions would help a more in-depth consideration of how the link between land and migration can be made more profitable for migrants, their families, and for West African society in general.

Author Contributions: M.K.: methodology, investigation, analysis, writing, and editing; G.B.: methodology, supervision, writing, editing, and review; G.S.: methodology, writing, editing, and review; A.L.: methodology, supervision, and review.

Funding: Research funds were provided by the Netherlands Land Academy on Land Governance, LANDac (www.landac.org).

Acknowledgments: We are indebted to the following researchers for the case studies on which this article is based: E. Eyebiyi (Benin); I. Sow and J. Nelen (Mali); and A. Zizien, F.K. Louré, and B.W. Sanou (Burkina Faso). In addition, we would like to thank two anonymous reviewers for their thoughtful and valuable comments.

Conflicts of Interest: The authors declare no conflict of interest.

\section{References}

1. Dietz, T.; Kaag, M.; De Vink, N. Thematic Map: Africa: International Migration, Emigration; African Studies Centre: Leiden, The Netherlands, 2017; Available online: https://openaccess.leidenuniv.nl/bitstream/ handle/1887/54691/20170922-Africa-Migration-GECORRIGEERD-PRINT.pdf? sequence=4 (accessed on 31 March 2019).

2. ICMPD. West Africa: Migration Flows Mostly Take Place Within the Region, not Outside. Available online: www.icmpd.org/news-centre/press-releases/west-africa-migration-flows-mostly-takes-placewithin-the-region-not-outside (accessed on 3 July 2015).

3. De Bruijn, M.; Van Dijk, R. (Eds.) Mobile Africa. Changing Patterns of Movement in Africa and Beyond; Brill: Leiden, The Netherlands, 2001.

4. ICMPD; IOM. A Survey on Migration Policies in West Africa; International Centre for Migration Policy Development: Vienna, Austria; The International Organization for Migration, Regional Office for West and Central Africa: Dakar, Senegal, 2015.

5. IPAR. Emploi des Jeunes et Migration en Afrique de l'Ouest. Rapport Final Sénégal; Initiative Prospective Agricole et Rurale: Dakar, Senegal, 2015.

6. Mercandalli, S.; Losch, B. (Eds.) Rural Africa in Motion. Dynamics and Drivers of Migration South of the Sahara; FAO and CIRAD: Rome, Italy, 2017.

7. Esson, J. Escape to victory: Development, youth entrepreneurship and the migration of Ghanaian footballers. Geoforum 2015, 64, 47-55. [CrossRef]

8. Langevang, T. 'We are managing!': Uncertain paths to respectable adulthoods in Accra, Ghana. Geoforum 2008, 39, 2039-2047. [CrossRef]

9. Honwana, A. The Time of Youth. Work, Social Change, and Politics in Africa; Kumarian Press: Sterling, TX, USA, 2012.

10. Steel, G.; Cottyn, I.; Van Lindert, P. New connections-New dependencies Spatial and digital flows in Sub-Saharan African livelihoods. In Livelihoods and Development. New Perspectives; De Haan, L., Ed.; Brill: Leiden, The Netherlands; Boston, MA, USA, 2018; pp. 148-167.

11. Cotula, L.; Toulmin, C. (Eds.) Till to Tiller: Linkages Between International Remittances and Access to Land in West Africa; IIED: London, UK; Edinburgh, UK, 2004.

12. Smith, L. Tied to Migrants. Transnational Influences on the Economy of Accra, Ghana; African Studies Centre: Leiden, The Netherlands, 2007.

13. Smith, L.; Mazzucato, V. Constructing homes, building relationships: Migrant investments in houses. Tijdschrift voor Economische en Sociale Geografie 2009, 100, 662-673. [CrossRef]

14. Tall, S.M. Investir Dans la Ville Africaine. Les Émigrés et L'habitat à Dakar; Karthala: Paris, France, 2009. 
15. Melly, C. Inside-out houses: Urban belonging and imagined futures in Dakar, Senegal. Comp. Stud. Soc. Hist. 2010, 52, 37-65. [CrossRef]

16. Gupta, J.; Pouw, N.; Ros-Tonen, M. Towards an elaborated theory of Inclusive development. Eur. J. Dev. Res. 2015, 27, 541-559. [CrossRef]

17. AUC/OECD. Africa's Development Dynamics 2018: Growth, Jobs and Inequalities; OECD Publishing: Paris, France; Addis Ababa, Ethiopia, 2018. [CrossRef]

18. Helmsing, B. A summary report prepared for the UNCDF symposium on decentralization local governance in Africa. In Local Economic Development New Generations of Actors, Policies and Instruments; Institute of Social Studies: The Hague, The Nederlands, 2011; Available online: http:/ /hdrnet.org/197/1/capetown_paper5. pdf (accessed on 11 February 2019).

19. Kaag, M. Linking-in through education? Exploring the educational question in Africa from the perspective of flows and (dis)connections. Sustainability 2018, 10, 496. [CrossRef]

20. Rakodi, C. Global forces, urban change, and urban management in Africa. In The Urban Challenge in Africa; Rakodi, C., Ed.; The United Nations University Press: New York, NY, USA, 1997; pp. 17-73.

21. Potts, D. Recent trends in rural-urban and urban-rural migration in sub-Saharan Africa: The empirical evidence and implications for understanding urban livelihood insecurity. In Environment, Politics and Development Working Paper Series; paper 6; Department of Geography, King's College London: London, UK, 2008.

22. Tacoli, C. Rural-urban interactions: A guide to the literature. Environ. Urban. 1998, 10, 147-166. [CrossRef]

23. Adepoju, A. Migration in Sub Saharan Africa; Current African issues. No. 37.; Nordiska Afrikainstitutet: Uppsala, Sweden, 2008.

24. Adepoju, A. Migration and Social Policy in Sub-Saharan Africa; IOM: Geneva, Switzerland, 2008.

25. Beauchemin, C. Rural-urban migration in West Africa: Towards a reversal? Migration trends and economic situation in Burkina Faso and Côte d'Ivoire. Popul. Space Place 2011, 17, 47-72. [CrossRef]

26. Devillard, A.; Bacchi, A.; Noack, M. Enquête sur les Politiques Migratoires en Afrique de l'Ouest; ICMPD: Vienna, Austria; OIM: Dakar, Senegal, 2016.

27. Diallo, A.O. Sénégal: Le chômage, une bombe à désarmorcer. Jeune Afrique, 31 May 2018.

28. Gillespie, T.A. Accumulation by urban dispossession: Struggles over urban space in Accra, Ghana. Transact. Inst. Br. Geogr. 2016, 41, 66-77. [CrossRef]

29. Cotula, L. The Great African Land Grab? Agricultural Investments and the Global Food System; Zed Books: London, UK, 2013.

30. Enda Pronat. Analyze et Mise en Perspective de Deux Systèmes de Production; Enda Pronat: Dakar, Senegal, 2017.

31. FAO; IFAD; IOM; WFP. The Linkages between Migration, Agriculture, Food Security and Rural Development; FAO: Rome, Italy, 2018.

32. CIA Factbook Country Pages Benin, Burkina Faso, Mali, Senegal. Available online: www.cia.gov/library/ publications/the-world-factbook/wfbExt/region_afr.html (accessed on 18 February 2019).

33. Eyebiyi, E. Jeunesse, Migration et Foncier Dans les Communes de Klouékanmè et Dogbo; VNG International: The Hague, The Netherlands, 2018.

34. Sow, I.; Nelen, J. Investissements Fonciers et Migration en Afrique de l'Ouest. Résultats de L'étude sur le Mali; Groupe Odyssée Mali: Bamako, Mali, 2018.

35. Zizien, A.; Louré, F.K.; Sanou, B.W. Jeunesse, Migration, Foncier et Développement Économique Local. Réalités et Perspectives Dans les Communes de Béguédo, Sapouy et Bama; Association Yiriwa: Ouagadougou, Burkina Faso, 2018.

36. Kaag, M.; Steel, G. Transnational migrants, land, and new investment hubs in African Cities. Built Environ. 2019, 44, 477-492. [CrossRef]

37. Kaag, M. Mouride transnational livelihoods at the margins of a European society: The case of residence Prealpino, Brescia, Italy. J. Ethn. Migr. Stud. 2008, 34, 271-285. [CrossRef]

38. Belachew, G. (Ed.) Africa and Fortress Europe: Threats and Opportunities; Rouletedge: Aldershot, UK, 2007.

39. Winters, N.; Drotbohm, H. Transnational Lives en Route: African Trajectories of Displacement and Emplacement across Central America. In Working Papers of the Department of Anthropology and African Studies of the Johannes Gutenberg; University Mainz: Mainz, Germany, 2018.

40. Langevang, T.; Gough, K.V. Surviving through movement: The mobility of urban youth in Ghana. Soc. Cult. Geogr. 2009, 10, 741-756. [CrossRef] 
41. Beauchemin, C.; Schoumaker, B. Are migrant associations actors in local development? A national event-history analysis in rural Burkina Faso. World Dev. 2009, 37, 1897-1913. [CrossRef]

42. ActionAid Kenya; ADECRU; Enda Pronat; Fórum Mulher; GROOTS Kenya; Oxfam in Malawi and LANDac. Women's Land Rights in Africa (WLRA): Scaling up Impacts from the Grassroots in Kenya, Malawi, Mozambique and Senegal; Synthesis report: Securing Women's Land Rights in Africa; LANDac: Utrecht, The Netherlands, 2018.

43. David, R. (Ed.) Changing Places? Women, Resource Management and Migration in the Sahel; SOS Sahel UK: London, UK, 1995.

44. Buggenhagen, B. Muslim Families in Global Senegal. Money Takes Care of Shame; Indiana University Press: Bloomington, IN, USA, 2012.

45. Smets, P.G.S.M. Housing Finance and the Urban Poor; Rawat: New Delhi, India; Jaipur, India, 2004.

46. Kaag, M.; Gaye, Y.; Kruis, M. Land Conflicts in senegal revisited: Continuities and emergent dynamics. In Land, Law and Politics in Africa. Mediating Conflict and Reshaping the State; Abbink, J., De Bruijn, M., Eds.; Brill Publishers: Leiden, The Netherlands, 2011; pp. 141-161.

(C) 2019 by the authors. Licensee MDPI, Basel, Switzerland. This article is an open access article distributed under the terms and conditions of the Creative Commons Attribution (CC BY) license (http://creativecommons.org/licenses/by/4.0/). 